\title{
FORMULASI SABUN LOSIO PENCUCI TANGAN (HAND WASH) GEL LIDAH BUAYA (Aloevera L.) DENGAN VARIASI EMULGATOR
}

\author{
Audia Triani Olii \\ Fakultas Farmasi Universitas Muslim Indonesia \\ Email : audhee jie@yahoo.com
}

\begin{abstract}
The aim of the research was to determine the optimum stable physically of the hand wash.Three formula were made in vary emulsifying agents that are Span 60Tween 60, TEA-Stearic acid and Sodium lauryl sulfate respectively. The assays carried out by accelerated condition on $5^{\circ} \mathrm{C}$ and $35^{\circ} \mathrm{C}$ for 10 cycles by which the parameter were emulsion type, creaming volume, viscosity and type of flow and dispersed globule measuring.Result showed that according to emulsion type all formula exhibited o/w indicated by blue color that even before and after conditioned. There were nothing of creaming volume in all formula. Statistic analyse in viscosity and flowing type showed that formula $A$ insignificant before and after conditioned, and has small dispersed globule. Rheogram showed close curve so that conclusion that might be taken that formula $A$ was the optimum one.
\end{abstract}

Keyword : Formulation, Hand wash, Aloevera L., Emulsifying.

\section{PENDAHULUAN}

Lidah buaya (Aloe vera) merupakan tanaman yang fungsional karena semua bagian dari tanaman dapat dimanfaatkan, baik untuk perawatan tubuh maupun untuk mengobati berbagai penyakit.

Cairan lidah buaya memiliki keasaman $(\mathrm{pH})$ yang natural yaitu 4,3 mirip dengan $\mathrm{pH}$ kulit manusia $4-6$. $\mathrm{Hal}$ ini dapat menghindari terjadinya iritasi kulit bagi pemakainya. Dari hasil penelitian sebelumnya yang dilakukan oleh irma wulandari dasril menunjukkan bahwa gel lidah buaya dapat membunuh bakteri
Staphylococcus aureus, Streptococcus mutans dan Vibrio sp pada konsenstrasi $7 \%$. Kandungan zat saponin dalam lidah buaya mempunyai kemampuan membersihkan dan bersifat antiseptik juga merupakan bahan pencuci yang sangat baik.

Pencuci tangan (Hand wash) adalah bahan yang mengandung sabun atau detergen lain, yang digunakan untuk tujuan membersihkan dengan menghilangkan kotoran dan atau mikroorganisme. Penggunaan air saja tidak efektif untuk membersihkan kulit karena air tidak dapat 
Formulasi Sabun Losio Pencuci Tangan (Hand Wash) Gel Lidah Buaya (Aloe vera L.) Dengan Variasi Emulgator

menghilangkan lemak, minyak, dan protein yang merupakan bahan organik. Untuk menghilangkan mikroorganisme dari kulit dibutuhkan penambahan sabun atau detergen, akan tetapi sabun murni tidak dapat membunuh mikroorganisme patogen (Anonim, 2008).

Sabun dalam bentuk losio emulsi dapat diberikan secara seragam dan lebih mudah digunakan karena losio dapat menyebar berupa lapisan tipis, sehingga lebih ekonomis dalam penggunaannya (Balsam, 1975).

Emulsi adalah sistem dua fase berupa cairan yang terdispersi seluruhnya dalam bentuk partikel kecil kedalam cairan lainnya yang tidak saling bercampur. Bahan yang digunakan untuk membentuk dan menstabilkan suatu emulsi disebut emulgator (Gennaro, 1990).

Emulgator atau bahan pengemulsi adalah partikel koloid yang mempunyai daya larut antara fase terdispersi dan médium pendispersi (Gennaro, 1990).

Beberapa macam emulgator berdasarkan struktur kimianya diklasifikasikan menjadi emulgator sintetik contoh Trietanolamin, Natriun laurel sulfat, Polisorbat dan Sorbitan monostearat, emulgator alam contoh akasia, gelatin dan lesitin, dan emulgator pembantu contoh Metil selulosa, asam stearat dan setil alkohol. Maka akan dilakukan penilitian Formulasi Gel Lidah Buaya (Aloe vera Linn) dengan menggunakan variasi emulgator.

\section{METODOLOGI PENELITIAN}

\section{Tempat Penelitian}

Penelitian ini dilaksanakan di Laboratorium Farmaseutika Fakultas Farmasi Universitas Muslim Indonesia, Makassar.

\section{Alat dan Bahan Yang Digunakan}

Alat-alat yang digunakan adalah batang pengaduk, gelas piala, gelas ukur, Erlemeyer, Dek gelas, objek gelas, lemari pendingin, mikroskop, penangas air, pengaduk elektrik, pipet volum, pipet tetes, termometer, dan timbangan analitik.

Bahan-bahan yang digunakan adalah Gel lidah buaya (Aloe vera), Air suling, Asam stearat, trietanolamin (TEA), Polisorbat 60, Sorbitan monostearat, natrium lauril sulfat, setil alkohol, parafin cair, gliserin, hidroksi etilselulosa (HEC), Metil paraben, Propil paraben, alfa tokoferol, dan Minyak mawar.

\section{Prosedur Kerja}

\section{Rancangan Formula}

Dirancang tiga formula sabun losio pencuci tangan yang 
Formulasi Sabun Losio Pencuci Tangan (Hand Wash) Gel Lidah Buaya (Aloe vera L.) Dengan Variasi Emulgator

mengandung Gel Lidah buaya dengan variasi emulgator. Pada formula pertama menggunakan polisorbat (Tween 60) dan Sorbitan monostearat (Span 60) sebagai emulgator, Formula kedua menggunakan emulgator Trietanolamin (TEA) dan Asam stearat dan formula ketiga menggunakan Natrium lauryl sulfat sebagai emulgator dengan alfa tokoferol sebagai antioksidan, setil alkohol sebagai emolien,parafin cair sebagai emolien, gliserin sebagai emolien, Propil paraben dan metal paraben sebagai pengawet fase air dan minyak, hidroksi etilselulosa sebagai pengental, dan Minyak mawar sebagai parfum.

\section{Pembuatan Sabun Losio Pencuci}

\section{Tangan}

Pembuatan emulsi sabun losio pencuci tangan dengan menggunakan emulgator Tween 60 dan Span 60

1. Ditimbang semua bahan sesuai perhitungan masing-masing.

2. Dilebur fase minyak yaitu setil alkohol, propil paraben, parafin cair, span 60, dan $\alpha$-tokoferol pada suhu $70^{\circ} \mathrm{C}$ diatas penangas sambil diaduk.

3. Fase air dibuat dengan mencampurkan metil paraben, gliserin, tween 60, hidroksi etil selulosa, dalam air dan dilebur sampai suhu $70^{\circ} \mathrm{C}$ sambil diaduk.

4. Dalam keadaan panas, fase minyak dimasukkan kedalam fase air yang berada dalam gelas kimia sedikit demi sedikit sambildiaduk dengan pengaduk elektrik kemudian ditambahkan gel lidah buayadan minyak mawar. Lalu diaduk kembali hingga membentuk losio emulsi.

Pembuatan emulsi sabun losio pencuci tangan dengan menggunakan emulgator TEA dan Asam stearat :

1. Ditimbang semua bahan sesuai perhitungan masing-masing.

2. Dilebur fase minyak yaitu setil alcohol, propil paraben, parafin cair, asam stearat, dan a-tokoferol pada suhu $70^{\circ} \mathrm{C}$ diatas penangas sambil diaduk.

3. Fase air dibuat dengan mencampurkan metil paraben,gliserin, trietanolamin, hidroksi etil selulosa, dalam air dan dilebur sampai suhu $70^{\circ} \mathrm{C}$ sambil diaduk.

4. Dalam keadaan panas, fase minyak dimasukkan kedalam fase air yang berada dalam gelas kimia sedikit demi sedikit sambildiaduk dengan pengaduk elektrik kemudian ditambahkan gel lidah buayadan minyak mawar. Lalu 
Formulasi Sabun Losio Pencuci Tangan (Hand Wash) Gel Lidah Buaya (Aloe vera L.) Dengan Variasi Emulgator

diaduk kembali hingga membentuk losio emulsi.

Pembuatan emulsi sabun losio pencuci tangan dengan menggunakan emulgator Natrium lauril sulfat

1. Ditimbang semua bahan sesuai perhitungan masing-masing.

2. Dilebur fase minyak yaitu setil alkohol, propel paraben, parafin cair, dan a-tokoferol pada suhu $70^{\circ} \mathrm{C}$ diatas penangas sambil diaduk.

3. Fase air dibuat dengan mencampurkan metil paraben,gliserin, hidroksi etil selulosa, natrium lauril sulfat , dalam air dan dilebur sampai suhu $70^{\circ} \mathrm{C}$ sambil diaduk.

4. Dalam keadaan panas, fase minyak dimasukkan kedalam fase air yang berada dalam gelas kimia sedikit demi sedikit sambildiaduk dengan pengaduk elektrik kemudian ditambahkan gel lidah buayadan minyak mawar. Lalu diaduk kembali hingga membentuk losio emulsi.

\section{Evaluasi Kestabilan Emulsi}

Evaluasi kestabilan emulsi dilakukan sebelum dan sesudah penyimpanan dipercepat pada suhu $5^{\circ}$ $C$ dan $35^{\circ}$ C secara bergantian masing - masing 12 jam selama 10 siklus.

\section{Pengukuran Volume Kriming}

Losio sebanyak $25 \mathrm{ml}$ ditempatkan dalam gelas ukur dan ditutup, kemudian disimpan pada kondisi dipaksakan yaitu suhu $5^{\circ} \mathrm{C}$ dan $35^{\circ} \mathrm{C}$ secara bergantian masing masing 12 jam.Kemudian diamati volume kriming yang terbentuk setiap satu siklus hingga siklus ke10.

\section{Pengujian Tipe Emulsi}

Emulsi sebanyak $5 \mathrm{ml}$ dimasukkan ke dalam gelas piala kemudian ditambahkan pewarna biru metilen $0,5 \mathrm{ml}$ kemudian diaduk dan selanjutnya diamati homogenitas warnanya untuk menentukan tipe emulsi M/A atau A/M.

\section{Pengukuran Viskositas dan}

\section{Penentuan Aliran Emulsi}

Sebanyak $60 \mathrm{ml}$ emulsi yang telah dibuat dimasukkan kedalam gelas kimia, kemudian diukur viskositasnya setelah pembuatan dan penyimpanan dipercepat dengan menggunakan viscometer Brookfield spindle 64 pada kecepatan 50 rpm dan diukur alirannya setelah pembuatan dan penyimpanan dipercepat dengan menggunakan viscometer Brookfield spindle 64 pada kecepatan 5,10, 20,30, 50 dan 60 rpm.

\section{Pengukuran Tetes terdispersi}

Losio sebanyak $10 \mathrm{ml}$ dimasukkan ke dalam vial $15 \mathrm{ml}$. 
Formulasi Sabun Losio Pencuci Tangan (Hand Wash) Gel Lidah Buaya (Aloe vera L.) Dengan Variasi Emulgator

pengamatan dilakukan dengan meneteskan emulsi pada objek gelas, kemudian ditutup dengan gelas penutup. Setelah itu diamati dengan menggunakan mikroskop, kemudian diambil gambarnya. Data berupa gambar diambil pada losio sebelum dan sesudah penyimpanan dipercepat.

\section{HASIL PENELITIAN}

Hasil penelitian dari beberapa parameter kestabilan sediaan sabun losio pencuci tangan gel lidah buaya dengan emulgator kombinasi tween 60 dan span 60 (A), kombinasi TEA dan asam stearat (B) dan natrium lauryl sulfat $(C)$ adalah sebagai berikut :

\section{Pengujian Tipe Emulsi}

\begin{tabular}{|c|c|c|c|c|c|c|}
\hline \multirow{3}{*}{ Tipe Emulsi } & \multicolumn{6}{|c|}{ Formula } \\
\hline & \multicolumn{2}{|c|}{ A } & \multicolumn{2}{|c|}{ B } & \multicolumn{2}{|c|}{ C } \\
\hline & $I$ & II & $I$ & II & $I$ & II \\
\hline $\mathrm{m} / \mathrm{a}$ & + & + & + & + & + & + \\
\hline $\mathbf{a} / \mathbf{m}$ & & & & & & \\
\hline
\end{tabular}

Keterangan :

$+\quad$ : Pada uji kelarutan warna, metilen biru nampak biru merata pada losio

I : : Losio sebelum kondisi dipercepat

II : : Losio setelah kondisi dipercepat

$\mathrm{m} / \mathrm{a} \quad$ : Tipe emulsi minyak dalam air

$\mathrm{a} / \mathrm{m}$ : Tipe emulsi air dalam minyak

\section{Volume Kriming}

Hasil pengamatan volume kriming sediaan sabun losio pencuci tangan yang dibuat dengan variasi emulgator menunjukkan bahwa pada formula $A, B$ dan formula $\mathrm{C}$ tidak mengalami kriming.

\section{Viskositas dan Tipe Aliran}

Pengukuran viskositas dengan menggunakan viskometer Brookfield pada kecepatan $50 \mathrm{rpm}$ dengan menggunakan spindel 64 menghasilkan nilai viskositas sabun losio pencuci tangan rata-rata sebelum dan sesudah penyimpanan dipercepat adalah :

\begin{tabular}{|c|c|c|c|c|}
\hline KONDISI & REPLIKASI & FORMULA A & FORMULA B & FORMULA C \\
\hline \multirow{3}{*}{ SEBELUM } & 1 & 40,8 & 80,8 & 58 \\
\cline { 2 - 5 } & 2 & 40,7 & 81 & 55,1 \\
\cline { 2 - 5 } & 3 & 40,8 & 81,5 & 54,8 \\
\hline \multirow{3}{*}{ SESUDAH } & 1 & 45,2 & 97,6 & 89,2 \\
\cline { 2 - 5 } & 2 & 35,6 & 115 & 87,8 \\
\cline { 2 - 5 } & 3 & 34,6 & 115,6 & 79,3 \\
\hline
\end{tabular}


Formulasi Sabun Losio Pencuci Tangan (Hand Wash) Gel Lidah Buaya (Aloe vera L.) Dengan Variasi Emulgator

\section{PEMBAHASAN}

Pencuci tangan (Hand wash) adalah bahan yang mengandung sabun atau detergen lain, yang digunakan untuk tujuan membersihkan dengan menghilangkan kotoran dan atau mikroorganisme. Penggunaan air saja tidak efektif untuk membersihkan kulit karena air tidak dapat menghilangkan lemak, minyak, dan protein yang merupakan bahan organik. Untuk menghilangkan mikroorganisme dari kulit dibutuhkan penambahan sabun atau detergen, akan tetapi sabun murni tidak dapat membunuh mikroorganisme patogen

Pada penelitian ini dibuat sabun losio pencuci tangan dengan menggunakan bahan aktif gel aloe vera $7 \%$ karena hasil penelitian sebelumnya yang dilakukan oleh irma wulandari dasril menunjukkan bahwa gel lidah buaya dapat membunuh bakteri Staphylococcus aureus, Streptococcus mutans dan Vibrio sp. Bahan tambahan lainnya yaitu gliserin sebagai emolien, hidroksi etilselulosa (HEC) sebagai pengental,setil alkohol sebagai emolien, Metil paraben dan Propil paraben sebagai pengawet, parafin cair sebagai emolien ,alfa tokoferol sebagai antioksidan, minyak mawar sebagai parfum dan variasi emulgator dari emulgator non ionik yaitu tween 60-span 60, emulgator sabun amin yaitu asam stearattrietanolamin dan emulgator detergen yaitu natrium lauryl sulfat. Emulgator tersebut dipilih karena merupakan golongan surfaktan yang merupakan bahan aktif permukaan yang menurunkan tegangan antarmuka antara minyak dan air dan mengelilingi tetesan terdispersi dengan membentuk lapisan yang kuat untuk mencegah koalesensi dan pemisahan fase terdispersi. Surfaktan memiliki daya kerja yang lebih tinggi dibandingkan emulgator lainnya seperti emulgator golongan hidrokolod.

Untuk memperoleh sediaan yang paling stabil dilakukan beberapa pengujian yaitu sebagai berikut :

\section{Pengujian Tipe Emulsi}

Pada pengujian tipe emulsi sediaan sabun losio pencuci tangan gel lidah buaya Formula $A$, B dan formula C dilakukan uji dispersi zat warna dengan menggunakan metilen biru dan menghasilkan warna biru yang homogen pada losio sebelum dan setelah penyimpanan dipercepat. Hal ini menunjukkan bahwa tipe emulsi adalah m/a.

Metilen biru mempunyai kelarutan pada air, apabila dicampur dengan emulsi m/a 
Formulasi Sabun Losio Pencuci Tangan (Hand Wash) Gel Lidah Buaya (Aloe vera L.) Dengan Variasi Emulgator

dimana emulsi ini memiliki fase air yang lebih banyak dibanding fase minyak, maka zat warna tersebut akan homogen pada losio sebaliknya apabila metilen biru dicampurkan pada emulsi a/m maka zat warna tersebut tidak homogen karena mempunyai fase minyak yang lebih banyak dibanding fase air.

Tidak berubahnya tipe emulsi sebelum dan sesudah kondisi dipercepat menandakan bahwa emulsi tersebut stabil. Maka dapat disimpulkan bahwa formula $A, B$ dan formula $C$ stabil karena tidak terjadi perubahan tipe emulsi sebelum dan setelah penyimpanan dipercepat.

\section{Pengukuran Volume Kriming}

Pada pengamatan volume kriming sebelum dan sesudah penyimpanan dipercepat pada formula A, B dan C tidak menunjukkan adanya kriming. Ini menandakan bahwa emulsi stabil. Hal ini disebabkan karena emulgator yang membentuk lapisan yang rapat disekeliling globul globul terdispersi.

Dibawah pengaruh gravitasi, partikel - partikel atau tetesan tetesan terdispersi cenderung meningkat atau mengendap, tergantung pada perbedaan dalam gravitasi spesifik antara fase tersebut. Partikel - partikel bulat yang pada dasarnya mempunyai ukuran yang sama, dan dipisahkan oleh suatu jarak yang membuat gerakan dari gerakan partikel lainnya. Pembentukan kriming meliputi gerakan sejumlah tetesan heterodispers, dan gerakan tersebut saling mengganggu satu sama lain dan bisa menyebabkan rusaknya tetesan. Emulgator yang digunakan dalam sediaan sabun losio pencuci tangan ini akan membentuk lapisan yang rapat disekeliling globul globul terdispersi, sehingga globul - globul tersebut tidak saling mengganggu satu sama lain.

\section{Viskositas}

Untuk pengukuran viskositas sediaan sabun losio pencuci tangan gel lidah buaya digunakan Viscometer Brookfield. Sediaan diukur dengan menggunakan spindel no 64, pada kecepatan rpm sebanyak tiga kali pengukuran.

Dari data pengujian dilakukan analisis secara statistik dengan menggunakan metode " Rancangan Acak Kelompok". Hasil yang diperoleh antara formula formula $\mathrm{A}, \mathrm{B}$ dan $\mathrm{C}$ menunjukkan nilai yang sangat berbeda nyata 
Formulasi Sabun Losio Pencuci Tangan (Hand Wash) Gel Lidah Buaya (Aloe vera L.) Dengan Variasi Emulgator

pada kondisi sebelum dan sesudah penyimpanan dipercepat, maka analisis dilanjutkan dengan uji BNT. Hasil uji lanjutan menunjukkan pada perbandingan antar kondisi formula A tidak berbeda nyata sedangkan formula B dan C sangat berbeda nyata pada kondisi sebelum dan sesudah penyimpanan dipercepat.

\section{Penentuan nilai yield}

Sifat aliran dapat ditentukan dengan membuat grafik hubungan antara "Shearing stress" (tekanan geser) dan "Rate of shear" (kecepatan geser). Melalui analisa data statistik menunjukkan bahwa formula A tidak berbeda nyata pada kondisi sebelum dan sesudah penyimpanan dipercepat. Hal ini menunjukkan tidak adanya pengaruh stress condition pada nilai yield.

\section{Tetes terdispersi}

Ukuran partikel atau ukuran tetes terdispersi merupakan parameter yang penting untuk evaluasi kesabilan emulsi. Ukuran rata-rata partikel atau tetesan terdispersi lebih kecil menghasilkan emulsi yang lebih stabil. Emulsi dengan distribusi ukuran partikel yang lebih seragam (homodispersi), lebih stabil jika dibandingkan dengan emulsi yang mempunyai distribusi partikel yang beragam (polydispersi) (Rosen Milton, 1976).

Pada pengamatan tetes terdispersi dapat dilihat pada gambar 10, 11 dan gambar 12. Gambar diambil dengan menggunakan mikroskop pada pembesaran $40 \times 10$. Dimana pada formula $A$ dan $C$ sebelum kondisi dipercepat memiliki ukuran tetes terdispersi yang kecil dibandingkan dengan formula B dan sesudah kondisi dipercepat terjadi penggabungan. Formula $\mathrm{B}$ dan $\mathrm{C}$ terjadi penggabungan yang lebih banyak dari pada formula A. Hal ini menunjukkan bahwa ukuran tetes terdispersi pada Formula A lebih seragam.

\section{Tipe Aliran}

Berdasarkan

hasil pengukuran yang diaplikasikan dalam bentuk rheogram sabun losio pencuci tangan formula $A, B$ dan formula $C$ menunjukkan tipe aliran plastis yaitu tidak melalui titik $(0,0)$. Pada formula A tidak terjadi perubahan yang besar pada bentuk rheogram antara sebelum dan sesudah penyimpanan dipercepat sedangkan pada formula $B$ dan $C$ memberikan hasil rheogram yang berbeda sebelum dan sesudah 
Formulasi Sabun Losio Pencuci Tangan (Hand Wash) Gel Lidah Buaya (Aloe vera L.) Dengan Variasi Emulgator

penyimpanan dipercepat. Hal ini menunjukkan bahwa Formula $\mathrm{A}$ memiliki daya alir yang stabil dibandingkan dengan formula $B$ dan C.

\section{KESIMPULAN}

Berdasarkann hasil penelitian dapat disimpulkan bahwa formula yang memiliki kestabilan optimal untuk sabun losio pencuci tangan (Hand Wash) gel lidah buaya (Ale vera $\mathrm{L}$ ) adalah Formula $\mathrm{A}$ dengan emulgator span 60-tween 60.

\section{DAFTAR PUSTAKA}

Anonim, 2008, Hand Washing online, (http://en.wikipedia.

Org),

Diakses 2 Desember 2008.

Ansel H.C., 1989., Pengantar Benetuk Sedian Farmasi Edisi 4., Penerbit Universitas Indonesia UI-Press., Yakarta.

Balsam.M.S., (1972), Cosmetics Science and Tehcnology, John Wileyand Sons, Inc, New York.

Banker, G.S., and Rhodes, C.T., 1995., Modern Pharmaceutics., Third Edition, Marcel Dekker, Inc., New York.

Ditjen POM., 1979., Farmakope Indonesia Edisi 3., Departemen Kesehatan RI., Jakarta.

Ditjen POM., 1995., Farmakope Indonesia Edisi 4., Departemen Kesehatan RI., Jakarta.

Furnawanthy.I, 2002, Khasiat dan Manfaat Lidah Buaya, Agromedia Pustaka
Gage. D, Tanpa tahun, Buku Pintar Terapi Aloe vera, Taramedia dan Restu Agung, Jakarta.

Gennaro A.R., 1990.,Remington's Pharmaceutical Sciences, $18^{\text {th }}$ edition., Mack Publishing Company., Easton, Pennsylvania.

Gennaro A.R., 1995., Remington's Pharmaceutical Sciences, $20^{\text {th }}$ edition., Mack Publishing Company., Easton, Pennsylvania

Kibbe, A. H., 2000.,l book of Pharmaceutical 1 ients, $3^{\text {rd }}$ Edition, American Assosiation Press, Washington D. C .

Lachman, L., Lieberman, H.A., and Kanig, J.L., 1986., Teori dan Praktek Farmasi Industri, Edisi Pertama, Universitas Indonesia.

Martin, E. W., 1971., Dispensing of Medication., Mack Publishing Company, Easton Pennsylvania.

Martin A., Swarbrick J., Cammarata A., (1990), Farmasi Fisik, Edisi 3, Penerbit Universitas Indonesia UI-Press., Jakarta.

Parrot, E.L., 1971.,Pharmaceutical Technology : Fundamental Pharmaceutics, Burgess Publishing Company, Minneapolis.

Rosen, Milton, J., 1976, Surfactan and Interfacial Phenomena, A Wiley Interscience Publication, John Wiley And Sons Inc.

Sprowl, J. B., 1970, Prescription Of Pharmachy, Second Edition, J.B. Lippincott Co., Philadelphia, Toronto. 